\title{
Turtle cleaners: reef fishes foraging on epibionts of sea turtles in the tropical Southwestern Atlantic, with a summary of this association type
}

\author{
Cristina Sazima ${ }^{1}$, Alice Grossman ${ }^{2}$ and Ivan Sazima ${ }^{3}$
}

In the present study we record several instances of reef fish species foraging on epibionts of sea turtles (cleaning symbiosis) at the oceanic islands of Fernando de Noronha Archipelago and near a shipwreck, both off the coast of Pernambuco State, northeast Brazil. Nine reef fish species and three turtle species involved in cleaning are herein recorded. Besides our records, a summary of the literature on this association type is presented. Postures adopted by turtles during the interaction are related to the habits of associated fishes. Feeding associations between fishes and turtles seem a localized, albeit common, phenomenon.

No presente estudo registramos diversos episódios de peixes recifais alimentando-se de epibiontes sobre o corpo de tartarugas marinhas (simbiose de limpeza) nas ilhas oceânicas do arquipélago de Fernando de Noronha e próximo a um naufrágio na costa de Pernambuco, nordeste do Brasil. Nove espécies de peixes recifais e três espécies de tartarugas envolvidas nas associações são aqui registradas. Além de nossos registros, apresentamos também um resumo da literatura sobre o tema. As posturas adotadas pelas tartarugas durante as interações estão relacionadas com os hábitos dos peixes associados. Associações alimentares entre peixes e tartarugas podem ser consideradas como um fenômeno local, embora comum.

Key words: Cleaning symbiosis, Foraging association, Cheloniidae, Tropical Western Atlantic.

Red, brown, and green algae, besides a variety of sessile and vagile animals may be found dwelling on hard and soft parts of sea turtles (e.g. Dodd, 1988; Hirth, 1997; Schärer, 2003; C. Sazima et al., 2004). These organisms are likely disadvantageous to the turtles since, besides removing the organisms by themselves (e.g. Losey et al., 1994; Schofield et al., 2006), the turtles allow reef fishes to feed on these epibionts (Booth \& Peters, 1972; Smith, 1988), and also seek particular cleaning stations on the reef to be cleaned by fishes and even shrimps (Losey et al., 1994; C. Sazima et al., 2004; I. Sazima et al., 2004; Grossman et al., 2006; Schofield et al., 2006). While the fishes feed on the organisms, the turtles get rid of the inconvenient epibionts and, thus, cleaning and grazing on turtles by reef fishes is regarded as an association that benefits both involved parts.

Grazing and cleaning by fishes on body parts of sea turtles are recorded both for the Atlantic and the Pacific oceans (e.g.
Booth \& Peters, 1972; Losey et al., 1994; C. Sazima et al., 2004). Three species of turtles of the Cheloniidae are recorded associated with reef fishes that graze on or clean epibionts (including ectoparasites), and presumably also remove diseased/dead tissue, namely the green turtle, Chelonia mydas (Booth \& Peters, 1972; Losey et al., 1994; C. Sazima et al., 2004), the hawksbill turtle, Eretmochelys imbricata (Smith, 1988; Grossman et al., 2006) and the loggerhead turtle, Caretta caretta (Schofield et al., 2006). On the other hand, at least 12 reef fish species within five families are recorded feeding on epibionts of sea turtles (Booth \& Peters, 1972; Smith, 1988; Losey et al., 1994; C. Sazima et al., 2004; Grossman et al., 2006; Schofield et al., 2006).

Data from literature indicates that cleaning of sea turtles by reef fishes is a widespread association. However, it has been suggested that this type of association might be localized in space and/or time, or restricted to specific populations of

${ }^{1}$ Departamento de Biologia Animal, Universidade Estadual de Campinas, 13083-970 Campinas, SP, Brazil. csazima@gmail.com

${ }^{2}$ All Angle Images Ltda., 53990-000 Fernando de Noronha, PE, Brazil.

${ }^{3}$ Museu de Zoologia, Universidade Estadual de Campinas, 13083-970 Campinas, SP, Brazil (retired and associated as voluntary researcher). 
turtles and/or fishes (Losey et al., 1994; C. Sazima et al., 2004; Grossman et al., 2006). Herein we report on additional instances of reef fishes cleaning sea turtles off northeastern Brazil, tropical Southwestern Atlantic, and evaluate the above-mentioned suggestion by presenting a summary on reef fishes cleaning and grazing on epibionts of sea turtles and, thus, provide a better view of this association.

The associations between reef fishes and sea turtles were recorded mostly at Fernando de Noronha Archipelago (0350'S $32^{\circ} 25^{\prime} \mathrm{W}$ ), off northeastern Brazil (see Maida \& Ferreira, 1997 for map and description), and near the shipwreck 'Pirapama', on the coast of Pernambuco state $\left(08^{\circ} 03^{\prime} \mathrm{S} 34^{\circ} 46^{\prime} \mathrm{W}\right)$, also off northeastern Brazil. These associations were recorded in January 2006; October 2006; October 2007; December 2008; February and October 2008, while snorkeling or scuba diving. Focal animal samplings were used throughout the observations (30-120 min, 10 dives), in which all occurrences of specified behaviors were recorded (Altmann, 1974; Lehner, 1979). Besides records penciled on plastic slates, the behavior of both the fishes and the turtles was photographed. Sizes of turtles are estimates of straight carapace length (SCL), and sizes of fishes are estimates of total length (TL). Associations in the archipelago were recorded at the Baía do Sueste and Cabeço da Caieiras. The former site is an inlet with an inner protected reef flat and shallow area near shore, and an outer reef slope leading to deeper parts (see C. Sazima et al., 2004 for figure). Depths in the Baía do Sueste vary 1-5 m. The Cabeço da Caieiras is a large rocky outcrop almost reaching the sea surface, with rocks and numerous cobbles scattered on the adjacent sand flat; the base of the outcrop is at 16-17 $m$ depth (Linsker, 2003). Additional associations were recorded on the sand flat adjacent to the shipwreck Pirapama, at a depth of $23 \mathrm{~m}$.

A hawksbill turtle (Eretmochelys imbricata) $85 \mathrm{~cm}$ was recorded moving and sometimes hovering in the water column near the above mentioned shipwreck with a group of blue tangs, Acanthurus coeruleus (12-25 cm), grazing on epibionts on the turtle's shell and nibbling at its neck and flippers (Fig. 1a). One porkfish, Anisotremus virginicus $(15 \mathrm{~cm})$ and one doctorfish, Acanthurus chirurgus $(20 \mathrm{~cm})$, were foraging on epibionts on the carapace of this same hawksbill turtle as well (Fig. 1a). On another occasion, an individual of the Brazilian endemic Zelinda's parrotfish, Scarus zelindae $(25 \mathrm{~cm})$, was recorded grazing on epibionts on the shell of an adult male loggerhead turtle (Caretta caretta) about $75 \mathrm{~cm}$ (Fig. 1b). Three blue tangs, Acanthurus coeruleus (18-24 cm), also grazed on the shell, and four Spanish hogfishes, Bodianus rufus (8$22 \mathrm{~cm}$ ), cleaned epibionts both on soft and hard parts of this same individual turtle (Fig. 1c).

A green turtle (Chelonia mydas) $55 \mathrm{~cm}$ was recorded at the Baía do Sueste seeking a particular spot on the reef flat (Fig. 1d), which seemed to be a cleaning station composed of rocky outcrops. The turtle approached the outcrops and rested on the bottom partly wedged under a ledge, a few small juveniles of the doctorfish, Acanthurus chirurgus $(5-7 \mathrm{~cm})$, small juveniles of the smallmouth grunt, Haemulon chrysargyreum $(6-8 \mathrm{~cm})$ and an adult Brazilian blenny, Ophioblennius trinitatis $(9 \mathrm{~cm})$ nibbling at the turtle's carapace. The blenny left the ledge where the turtle was partly underneath and moved across the turtle's carapace plucking algae attached to the shell (Fig. 1d). Three individuals of the Rocas damselfish, Stegastes rocasensis $(5-8 \mathrm{~cm})$, also nibbled at the flippers and shell of the same turtle during the time it stayed there. On three different occasions, green turtles (three individuals 45, 50 and $53 \mathrm{~cm}$ ) were recorded moving to particular spots within the inlet, near rocky outcrops, and posing at mid-water (Fig. 1e) for small groups of sergeant majors, Abudefduf saxatilis (10-12 cm). The turtles remained almost motionless, hovering at mid-water while being inspected and cleaned on the shell, neck and flippers by the fish (Fig. 1e).

At the Cabeço da Caieiras, a green turtle $40 \mathrm{~cm}$ was recorded resting on the bottom near algae turfs tended by a Rocas damselfish $(7 \mathrm{~cm})$. The turtle remained motionless with its hind limbs sprawled and the forelimbs stretched holding its fore body and head elevated, while the damselfish nibbled at the hind limbs (Fig. 1f).

The green turtle (Chelonia mydas) has the highest number of associated fish species, with a total of 12 species grazing on or cleaning its body from epibionts, both in the Atlantic and the Pacific oceans (Table 1). The present study adds three new reef fish species to this association in the Atlantic, namely Ophioblennius trinitatis, Haemulon chrysargyreum and Stegastes rocasensis (Table 1). Additionally, we recorded Abudefduf saxatilis foraging on epibionts on the carapace, previous records mentioning this fish species cleaning the soft parts only (Table 1). Six fish species forage on epibionts that dwell on the hawksbill turtle (Eretmochelys imbricata), three of them new records: Acanthurus chirurgus, A. coeruleus and Anisotremus virginicus (Table 1). Moreover, we recorded Abudefduf saxatilis feeding on epibionts on the hard parts of this turtle, previous records mentioning this fish nibbling at the soft parts only (Table 1). Records of fishes associated with E. imbricata are restricted to the Atlantic Ocean (Table 1). The loggerhead turtle (Caretta caretta) has here three new fish species added to this association type, namely Scarus zelindae, Acanthurus coeruleus, and Bodianus rufus, from a total of four species recorded so far (Table 1). Records of fishes associated with the loggerhead turtle also are restricted to the Atlantic Ocean (Table 1). The present study adds two new fish families associated with sea turtles, namely Blenniidae and Haemulidae (Table 1). Additionally, five reef fish species are herein added to those previously recorded in this association type (Table 1).

Fish species that forage on the epibionts of sea turtles are herbivorous, zoobenthivorous, or omnivorous. Since turtles bear a variety of algal growth on their bodies (e.g. Sentíes et al., 1999; Báez et al., 2002; C. Sazima et al., 2004), we surmise that herbivorous fishes are primarily feeding on this type of epibiont. However, some herbivores such as surgeonfishes (Acanthuridae), may supplement their diets with detritus, benthic micro-fauna, and plankton (Randall, 1967; Duarte \& 

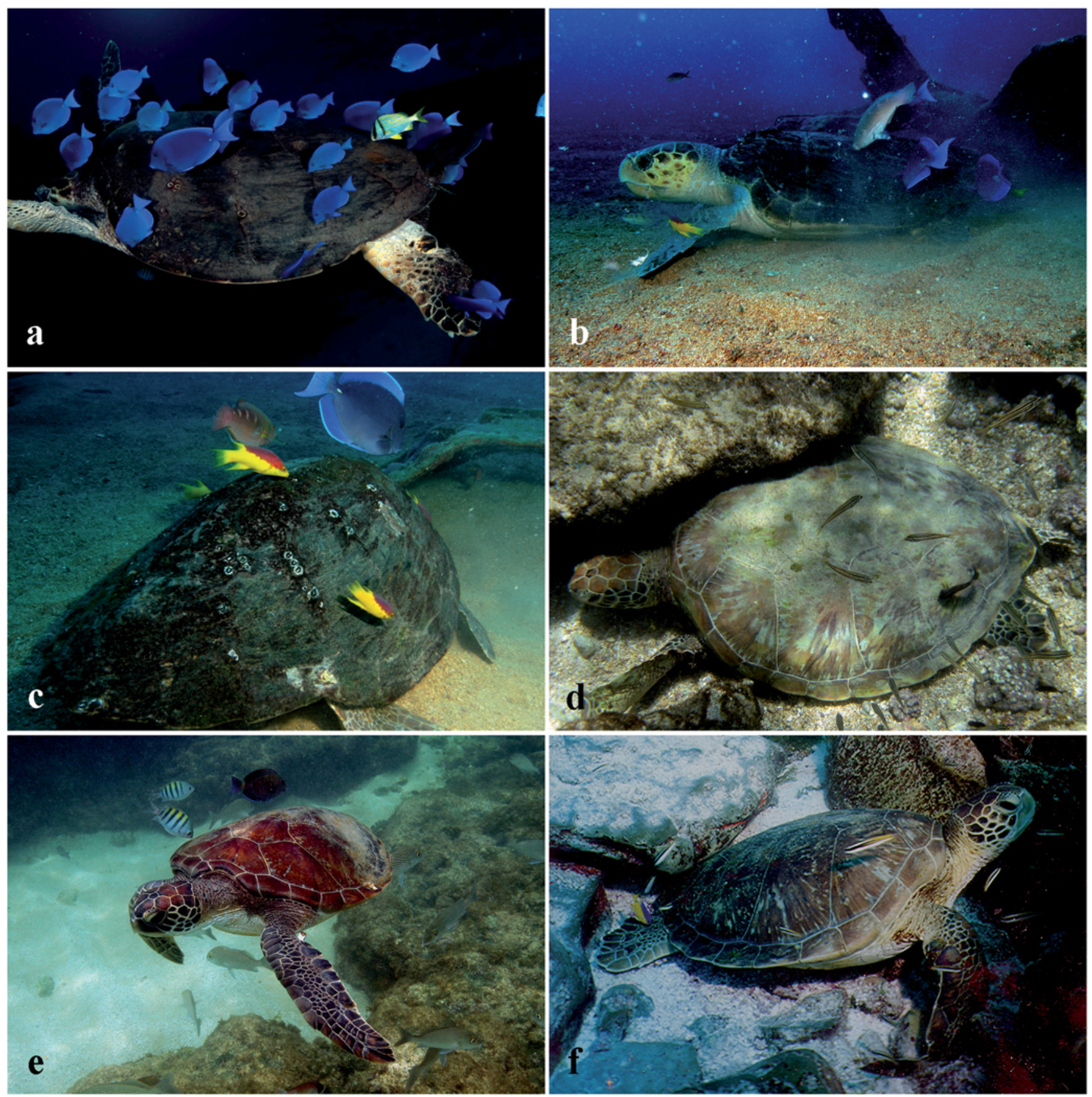

Fig. 1. Reef fishes cleaning sea turtles' hard and soft parts in the Southwestern Atlantic. A porkfish (Anisotremus virginicus) and a group of blue tangs (Acanthurus coeruleus) feed on epibionts on the shell of a moving hawksbill turtle (Eretmochelys imbricata); a barely visible doctorfish (Acanthurus chirurgus) nibbles at the posterior portion of the turtle's shell, and two blue tangs nibble at the left hind limb (a). Photo by M. Granville. One Zelinda's parrotfish (Scarus zelindae) and three blue tangs feed on algae growth on the shell of a male loggerhead turtle (Caretta caretta) near a shipwreck; two Spanish hogfishes (Bodianus rufus) also inspect the turtle (b). Photo by Z. Matheus. Four Spanish hogfish inspect and forage on epibionts on the shell of the same loggerhead turtle; one blue tang and one Zelinda's parrotfish also "escort" the slowly moving turtle (c). Photo by Z. Matheus. A green turtle (Chelonia mydas) remain motionless on the bottom, while a Brazilian blenny (Ophioblennius trinitatis) forages on algae growth on the left lateral portion of the shell; a few smallmouth grunts (Haemulon chrysargyreum) also capitalize upon this situation, and nibble at the turtle's shell (d). Photo by C. Sazima. A sergeant major (Abudefduf saxatilis) nibbles at an algae patch on the anterior part of the shell of a posing and hovering green turtle (e). Photo by Z. Matheus. The herbivorous Rocas damselfish (Stegastes rocasensis) nibbles at the right hind limb of a green turtle posing near algae turfs tended by this damselfish (f). Photo by Z. Matheus. 
Acero, 1988), in which case these fishes may also seek other organisms dwelling on the turtles (see C. Sazima et al., 2004 for this view). The damselfish Stegastes rocasensis (Pomacentridae) feeds both on shell and skin areas (present study), and likely forages on algae and attached animals as well (Randall, 1967). Zoobenthivorous species likely seek small invertebrates, be it on the shell in the case of grunts, Haemulidae (present study), or on the skin in the case of wrasses, Labridae (Booth \& Peters, 1972; Losey et al., 1994). Omnivorous species, such as sergeant majors (Pomacentridae), probably seek both algae and small invertebrates, feeding on epibionts both on the shell and skin (Booth \& Peters, 1972; C. Sazima et al., 2004; Grossman et al., 2006; present study). Irrespective of their feeding category, fish species that forage on epibionts and/or tissues of turtles likely consider these latter as extensions of their foraging grounds, even if temporary. This was particularly apparent in the case of the Brazilian blenny (O. trinitatis), which left its feeding territory to pluck algae on the shell of a green turtle - a transitory feeding ground immediately adjacent to its territory on the ledge.

Parrotfishes (Labridae, Scarini) are major algae consumers in coral reef communities (Choat 1991; Cowman et al., 2009). The jaw morphology and general habits of the parrotfish Scarus zelindae, herein recorded associated with C. caretta, indicate that it forages by scraping. Scrapers have a mobile and complex jaw articulation with slender musculature and a non-excavating bite that restrict them to removal of algae from the substratum surface only (Streelman et al., 2002). The phylogeny presently available for parrotfishes indicates that most, if not all, species within the genus Scarus are scrapers (Streelman et al., 2002; Cowman et al., 2009). The single previous record (a brief mention) of a parrotfish grazing on turtles' epibionts is an unidentified species of Scarus (Losey et al., 1994). Juvenile parrotfishes act as scrapers, whereas adults may act as scrapers or excavators (Bellwood \& Choat, 1990; Francini-Filho et al., 2008). Thus, the species notwithstanding, we suggest that among Scarini those that forage by scraping are the most likely to be recorded foraging on epibionts of sea turtles, as the substrate is adequate for this feeding mode.

All three turtle species here recorded in association with reef fishes adopt characteristic postures and behaviors at the cleaning stations (e.g. Booth \& Peters, 1972; Grossman et al.,

Table 1. Reef fishes recorded cleaning sea turtles in the Atlantic (A) or the Pacific (P) oceans. "Soft" refers to fishes foraging on the surface of soft body parts (head, neck, flippers), whereas "hard" refers to foraging on the surface of hard body parts (carapace, plastron). Turtle species in alphabetical order, and fish families and species arranged similarly for each turtle species.

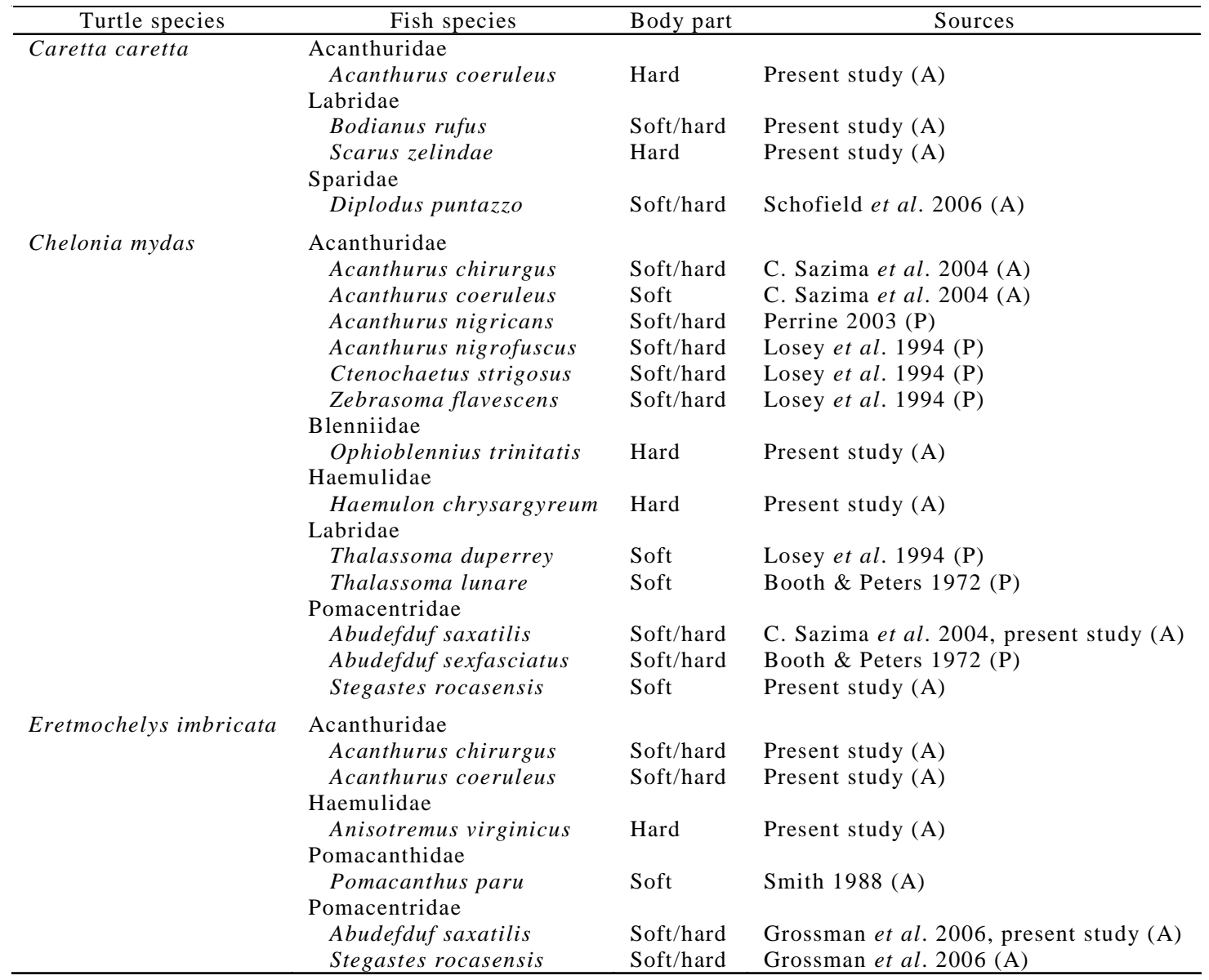


2006; Schofield et al., 2006). The postures may be displayed both in the water column and on the bottom, and they follow a pattern. In general, turtles being grazed or cleaned in the water column remain hovering almost motionless with their flippers extended and drooped downward, often with the neck extended and bent downward (Booth \& Peters, 1972; Losey et al., 1994; C. Sazima et al., 2004; Grossman et al., 2006). On the other hand, turtles being grazed or cleaned on the bottom remain almost motionless, with their hind limbs sprawled and the forelimbs stretched often holding the fore body and head elevated (Grossman et al., 2006; Schofield et al., 2006; present study). Apparently, there is no specificity between a turtle species and a particular posture. Specificity of a given posture, however, seems to be related to the cleaner's habits. When the turtle is cleaned by benthopelagic fishes such as wrasses, it tends to hold a stationary position in the water column. On the other hand, when cleaned by a strictly benthic species such as the Brazilian blenny, the turtle tends to hold a stationary position on the bottom. Additionally, this position on the bottom is adopted by turtles being cleaned by shrimps that dwell in rock crevices (I. Sazima et al., 2004). However, most reef fishes associated with sea turtles (such as surgeonfishes, sergeant majors, and some wrasses) are able to forage on epibionts both on resting or hovering turtles, in which case the turtles may adopt either posture. Another characteristic that likely influences the posture adopted by a turtle is whether it is cleaned while feeding/moving, or whether it seeks a station to be cleaned.

As previously suggested (Losey et al., 1994; C. Sazima et al., 2004; Grossman et al., 2006), interactions between reef fishes and sea turtles may indeed be a localized phenomenon. We surmise that if this association type is actually restricted to particular populations and/or individuals, this may be due (at least partly) to the fact that this interaction requires learning from both the turtles and the fishes (Losey et al., 1994; Grossman et al., 2006). However, taken together, data from literature and the present study indicate that reef fishes that graze on, clean, or 'use' turtles otherwise as feeding grounds are commoner than the available records would denote.

\section{Acknowledgements}

We thank Zaira Matheus and Marta Granville for the superb photographs; FAPESP and CNPq for essential financial support; José Martins Silva Jr. (Projeto Golfinho Rotador) for logistical support; the ICMBio for issuing study permits to study reef fishes at Fernando de Noronha Archipelago.

\section{Literature Cited}

Altmann, J. 1974. Observational study of behavior: sampling methods. Behaviour, 49: 227-265.

Báez, J. C., J. A. Camiñas, J. Valeiras, F. Conde \& A. Flores-Moya. 2002. Preliminary check-list of the epizootic macroalgae growing on loggerhead turtles in the western Mediterranean Sea. Marine Turtle Newsletter, 98: 1-2.
Bellwood, D. R. \& J. H. Choat. 1990. A functional analysis of grazing in parrotfishes (family Scaridae): the ecological implications. Environmental Biology of Fishes, 28: 189-214.

Booth, J. \& J. A. Peters. 1972. Behavioural studies on the green turtle (Chelonia mydas) in the sea. Animal Behaviour, 20: 808-812.

Choat, J. H. 1991. The biology of herbivorous fishes on coral reefs. Pp. 120-155. In: Sale, P. F. (Ed.). The ecology of fishes on coral reefs. San Diego, Academic Press, 754p.

Cowman, P. F., D. R. Bellwood \& L. van Herwerden. 2009. Dating the evolutionary origins of wrasse lineages (Labridae) and the rise of trophic novelty on coral reefs. Molecular Phylogenetics and Evolution, 52: 621-631.

Dodd, C. K., Jr. 1988. Synopsis of the biological data on the loggerhead sea turtle Caretta caretta (Linnaeus 1758). US Fish and Wildlife Service Biological Report, 88: 1-110.

Duarte, C. S. A. \& A. Acero P. 1988. Hábitos alimentarios de los peces del género Acanthurus (Perciformes: Acanthuridae) en la región de Santa Marta (Caribe colombiano). Revista de Biología Tropical, 36: 399-405.

Francini-Filho, R. B., R. L. Moura, C. M. Ferreira \& E. O. C. Coni. 2008. Live coral predation by parrotfishes (Perciformes: Scaridae) in the Abrolhos Bank, eastern Brazil, with comments on the classification of species into functional groups. Neotropical Ichthyology, 6(2): 191-200.

Grossman, A., C. Sazima, C. Bellini \& I. Sazima. 2006. Cleaning symbiosis between hawksbill turtles and reef fishes at Fernando de Noronha Archipelago, off Northeast Brazil. Chelonian Conservation and Biology, 5(2): 284-288.

Hirth, H. F. 1997. Synopsis of the biological data on the green turtle Chelonia mydas (Linnaeus 1758). US Fish and Wildlife Service Biological Report, 97: 1-120.

Lehner, P. N. 1979. Handbook of ethological methods. New York, Garland STPM Press, 403p.

Linsker, R. 2003. Arquipélago Fernando de Noronha, o paraíso do vulcão. São Paulo, Terra Virgem, 167p.

Losey, G. S., G. H. Balazs \& L. A. Privitera. 1994. Cleaning symbiosis between the wrasse, Thalassoma duperrey, and the green turtle, Chelonia mydas. Copeia, 1994(3): 684-690.

Maida, M. \& B. P. Ferreira. 1997. Coral reefs of Brazil: an overview. Proceedings of the 8th International Coral Reef Symposium, 1: 263-274.

Perrine, D. 2003. Sea turtles of the world. Stillwater, Voyageur Press, 144p.

Randall, J. E. 1967. Food habits of reef fishes of the West Indies. Studies on Tropical Oceanography, 5: 665-847.

Sazima, C., A. Grossman, C. Bellini \& I. Sazima. 2004. The moving gardens: reef fishes grazing, cleaning, and following green turtles in SW Atlantic. Cybium, 28: 47-53.

Sazima, I., A. Grossman \& C. Sazima. 2004. Hawksbill turtles visit moustached barbers: cleaning symbiosis between Eretmochelys imbricata and the shrimp Stenopus hispidus. Biota Neotropica, 4(1): 1-6.

Schärer, M. T. 2003. A survey of the epibiota of Eretmochelys imbricata (Testudines: Cheloniidae) of Mona Island, Puerto Rico. Revista de Biologia Tropical, 51(4): 87-90.

Schofield, G., K. A. Katselidis, P. Dimopoulos, J. D. Pantis \& G. C. Hays. 2006. Behaviour analysis of the loggerhead sea turtle Caretta caretta from direct in-water observation. Endangered Species Research, 2: 71-79.

Sentíes G., A., J. Espinoza-Avalos \& J. C. Zurita. 1999. Epizoic algae of nesting sea turtles Caretta caretta (L.) and Chelonia mydas (L.) from the Mexican Caribbean. Bulletin of Marine Science, 64(1): 185-188. 
Smith, S. H. 1988. Cleaning of the hawksbill turtle (Eretmochelys imbricata) by adult french angelfish (Pomacanthus paru). Herpetological Review, 19: 55.

Streelman, J. T., M. Alfaro, M. W. Westneat, D. R. Bellwood \& S. A. Karl. 2002. Evolutionary history of the parrotfishes: biogeography, ecomorphology, and comparative diversity. Evolution, 56: 961-971.

Accepted December 4, 2009 